\title{
POTENSI GEOWISATA BUKIT JAMUR KECAMATAN BUNGAH, KABUPATEN GRESIK, PROVINSI JAWA TIMUR
}

\author{
I Putu Krishna Wijaya, Amien Widodo, \\ Jurusan Teknik Geofisika, ITS \\ Email: krishna_wijaya@yahoo.co.id
}

\begin{abstract}
Abstrak. Informasi geologi pada umumnya digunakan untuk kepentingan eksplorasi dalam bidang energi, pertambangan, keteknikan, dan lingkungan. Padahal dalam bidang pariwisata informasi geologi juga dapat digunakan untuk mendukung pengembangan suatu kawasan pariwisata khususnya wisata alam. Bukit Jamur di Kecamatan Bungah, Kabupaten Gresik memiliki keunikan dan nilai estetika yang layak untuk dijadikan sebagai suatu lokasi wisata. Bukit Jamur juga menarik dari sisi geologi karena merupakan bagian dari puncak antiklin yang telah tererosi. Bukit Jamur tersusun atas batu pasir karbonatan dan batu gamping terumbu (bafflestone) yang diinterpretasikan terbentuk di lingkungan reef front. Oleh karena itu, kawasan ini sangat berpotensi untuk dijadikan kawasan geowisata, laboratorium alam, dan sebagai tempat pembelajaran struktur geologi, stratigrafi, petrologi karbonat dan mixsilisiklastik maupun kuliah lapangan terutama bagi mahasiswa geosains.
\end{abstract}

Kata Kunci: Bukit Jamur, geowisata, batu gamping terumbu, Bungah-Gresik.

Abstract. Geological information are generally used for exploration purposes, especially for energy, mining, engineering and environmental. On the other hand, geological information can also be used to support tourism development such as natural park. Bukit Jamur where is located at District Bungah, Gresik, East Java has some criteria to be a tourist object. It has its own uniqueness and aesthetic. In geological view, Bukit Jamur is also potential to be a natural park because it is a part of eroded peak anticline. Bukit Jamur is composed by carbonaceous sand rocks and bufflestones and interpretively made in a reef front. Therefore, this site is very potential to be a natural park, natural laboratory, field of geology study, field of stratigraphy study, field of carbonate petrology study, and field camp for geoscience students.

Keywords: Bukit Jamur, natural park, bufflestone, Bungah-Gresik.

\section{PENDAHULUAN}

\section{Latar Belakang}

Informasi geologi pada umumnya digunakan untuk kepentingan eksplorasi dalam bidang energi, pertambangan, keteknikan, dan lingkungan. Padahal dalam sektor pariwisata informasi geologi juga dapat digunakan untuk mendukung pengembangan suatu kawasan pariwisata khususnya wisata alam. Dinamika proses geologi yang terjadi di Indonesia menjadikan Indonesia memiliki kenampakan geologi yang unik dan menarik sehingga dapat dijadikan sebagai laboratorium alam geologi maupun sebagai objek wisata yang memiliki aspek geologi atau dikenal dengan sebutan "geowisata".

Bukit Jamur di Kecamatan Bungah, Kabupaten Gresik memiliki nilai estetika tinggi atau memiliki aspek keindahan sebagai suatu lokasi wisata. Bukit Jamur juga menarik dari sisi geologi karena tersusun atas berbagai macam fosil organisme pembentuk reef yang kemudian menjadi batu gamping terumbu dan merupakan bagian dari suatu puncak antiklin (Antiklin Bungah). Sehingga kawasan ini memiliki potensi yang besar untuk digunakan sebagai kawasan geowisata.

\section{METODOLOGI PENELITIAN}

Metode penelitian yang digunakan adalah metode survei langsung terhadap kondisi geologi daerah penelitian yang meliputi pengamatan, pengukuran, pencatatan, dan deskripsi terhadap 
objek geologi yang ada di daerah kajian. Pengumpulan data sekunder berupa peta topografi, citra satelit, peta RBI, dan peta geologi regional yang nantinya akan digunakan sebagai peta dasar sebelum dilakukan pengumpulan data primer melalui survei lapangan.

\section{HASIL DAN PEMBAHASAN}

\section{Kesampaian Daerah}

Bukit Jamur terletak di lahan bekas penambangan galian $C$ di Desa Kaliwot, Kecamatan Bungah, Kabupaten Gresik, Provinsi Jawa Timur. Lokasi ini dapat ditempuh menggunakan kendaraan roda empat maupun roda dua dalam kurun waktu \pm 3 jam dengan mengikuti rute perjalanan melalui Surabaya menuju Gresik melalui jalur pantura kemudian melintasi jembatan yang berada di atas Sungai Bengawan Solo kemudian menuju lokasi penambangan batu gamping di Desa Kaliwot, Kecamatan Bungah. Lokasi ini terletak pada koordinat $7^{\circ} 2^{\prime} 33.5^{\prime \prime} \mathrm{S} \quad 112^{\circ} 33^{\prime} 59,6^{\prime \prime} \mathrm{E}$.

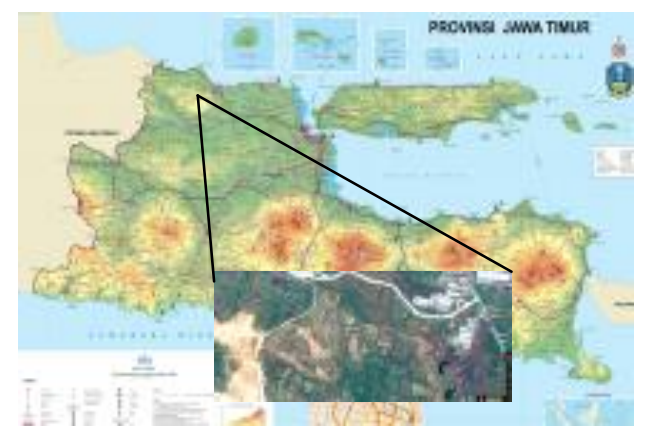

Gambar 1. Lokasi Penelitian Terletak di Desa Kaliwot, Kecamatan Bungah, Kabupaten Gresik.

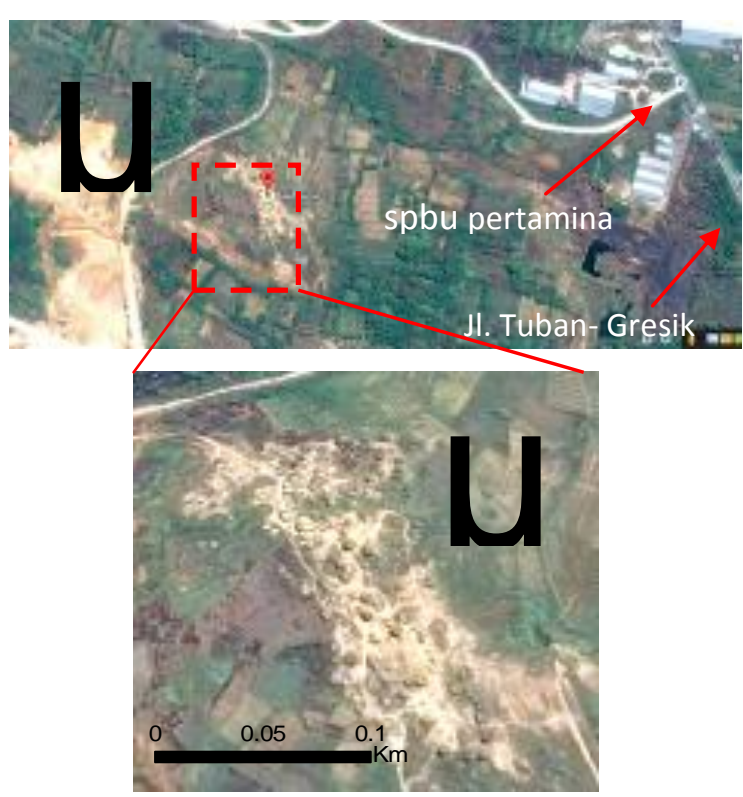

Gambar 2. Lokasi Penelitian dalam Citra Google Earth (ditandai dengan kotak berwarna merah).

\section{Kondisi Morfologi Daerah Penelitian}

Pengklasifikasian satuan geomorfologi pada daerah penelitian didasarkan pada aspek morfometri dengan memperhitungkan sudut lereng. Perhitungan kemiringan lereng (morfometri) dilakukan secara langsung di lapangan.

Kemiringan lereng di sekitar wilayah penelitian juga bervariasi berkisar dari $\leq 10^{\circ}->40^{\circ}$ sehingga dapat dibagi menjadi menjadi empat satuan morfologi yaitu satuan lereng landai $\left(\leq 10^{\circ}\right)$, lereng agak curam $\left(>10^{\circ}->20^{\circ}\right)$, curam $\left(>20^{\circ}-<40^{\circ}\right)$, dan lereng sangat curam $\left(>40^{\circ}\right)$.

Lokasi penelitian terletak pada kelas lereng curam $\left(>20^{\circ}-<40^{\circ}\right)$ (Gambar 3). Namun akibat proses penambangan kondisi bentang lahan terus mengalami degradasi sehingga morfologinya seiring berjalannya waktu semakin landai-datar. 


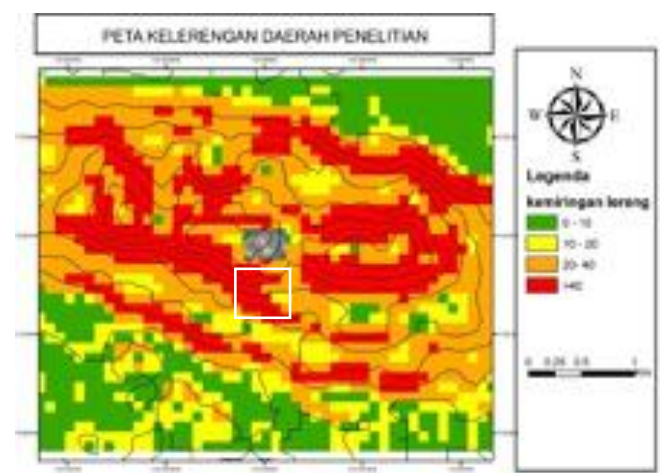

Gambar 3. Peta Kelerengan Daerah Penelitian

(lokasi penelitian ditandai dengan kotak berwarna putih).

\section{Kondisi Geologi Regional Daerah Penelitian}

Berdasarkan peta geologi lembar SurabayaSapulu oleh Supandjono dkk. (1992), secara regional daerah penelitian tersusun atas beberapa formasi batuan. Urutan formasi batuan dari tua ke muda yaitu Formasi Tawun, Formasi Watukoceng, Formasi Sonde, dan Formasi Madura (Gambar 4 dan Gambar 6). Bukit Jamur sendiri merupakan bagian dari Formasi Watukoceng yang tersusun atas selangseling napal pasiran dengan batu gamping.

Struktur geologi yang berkembang berupa lipatan, dimana lokasi penelitian merupakan bagian dari suatu puncak antiklin yang disebut sebagai Antiklin Bungah (Gambar 4 dan Gambar 5).

\section{Trmpm}

Formasi Madura: Bagian atas tersusun atas batu gamping terumbu, putih, pejal, berongga halus, dan setempat berlapis buruk mengandung foram besar dan pecahan ganggang. Tanahnya kecoklatan atau kehitaman. Bagian bawah tersusun atas batu gamping kapuran, sangat ringan, agak keras, putih kekuningan, dan pejal. Secara setempat berlapis buruk mengandung moluska, foram besar, dan pecahan ganggang.

\section{Tps}

Formasi Sonde: Tersusun atas napal tufan putih kekuningan, mengandung diatome, dan setempat bintal gampingan (calcareous nodules).

\section{Tniv}

Formasi Watukoceng: Bagian atas tersusun atas selang-seling napal pasiran dengan batu gamping. Bagian bawah tersusun atas batu pasir kuarsa bersisipan batu gamping orbitoid dan batu pasir berlapis tipis. Secara setempat terdapat perlapisan batu gamping kalkarenit.

\section{$\operatorname{Tm}$}

Formasi Tawun: Bagian atas tersusun atas napal pasiran bersisipan batu gamping dan batu pasir gampingan. Bagian bawah tersusun atas batu lempung gampingan berbintal gampingan (calcareous nodules).

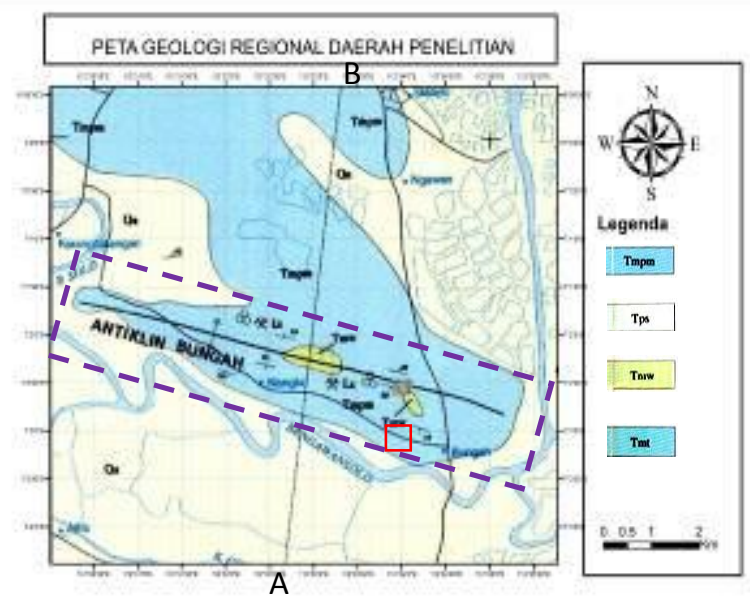

Gambar 4. Peta Geologi Regional Daerah Penelitian Supandjono dkk. (1992).

Lokasi penelitian (kotak berwarna merah) tersusun atas formasi Tmw, dan dikelilingi oleh merupakan bagian dari puncak Antiklin Bungah (ditandai formasi yang lebih muda (Tmpm). Lokasi penelitian (kotak dengan garis putus-putus berwarna ungu)

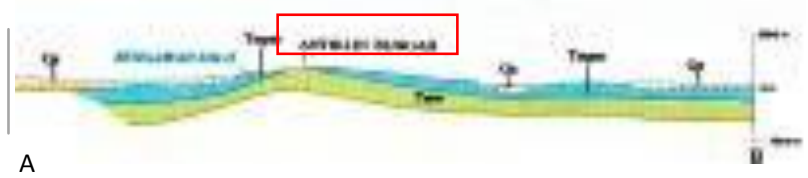

Gambar 5. Penampang Geologi A-B

Puncak Antiklin Bungah yang semula tersusun atas formasi Tmpm kemudian mengalami erosi sehingga menyingkap formasi yang ada di bawahnya yaitu formasi Tmw (lokasi Bukit Jamur saat ini), (Supandjono dkk.,1992). 

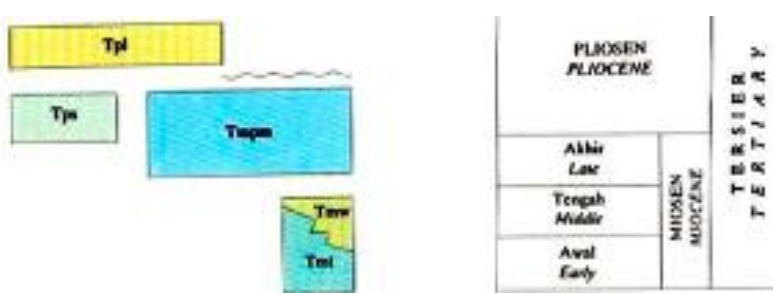

Gambar 6. Stratigrafi Regional Daerah Penelitian.

Formasi Tmw berumur miosen awal-miosen tengah, sedangkan formasi Tmpm berumur miosen akhir pliosen. (Supandjono dkk.,1992).

\section{Potensi Geowisata Daerah Penelitian}

Bukit Jamur sebenarnya merupakan lokasi bekas penambangan bahan galian $\mathrm{C}$ yang sudah ditinggalkan. Penamaan Bukit Jamur oleh masyarakat kemungkinan mengacu kepada kenampakan susunan bebatuan yang unik dan memiliki bentuk menyerupai jamur. Ketinggian susunan batuan ini bervariasi mulai dari $1 \mathrm{~m}$ hingga $6 \mathrm{~m}$.

Bukit Jamur memiliki kenampakan yang indah, menarik, dan unik sehingga berpotensi untuk dikembangkan sebagai kawasan wisata. Namun perlu diketahui bahwa bentukan sususan batuan yang menyerupai jamur ini bukanlah disebabkan karena proses alam seperti yang dipikirkan oleh sebagian besar masyarakat dan artikel dalam media internet.

Bukit Jamur pada awalnya merupakan kawasan penambangan bahan galian C. Pihak pengelola penambangan mengupas batuan bagian bawah yang berupa batu pasir karbonatan dan meninggalkan bagian atasnya yang lebih kompak dan pejal yang tersusun atas batu gamping terumbu.

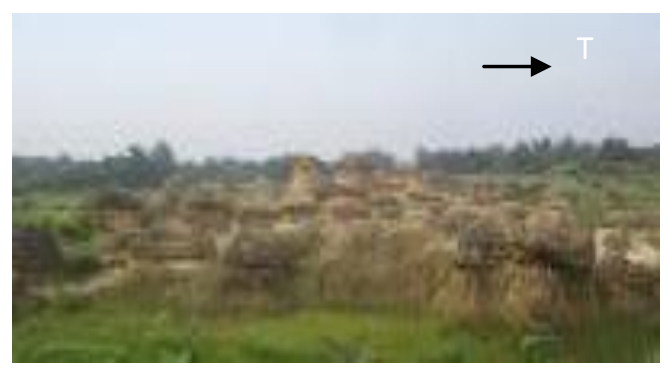

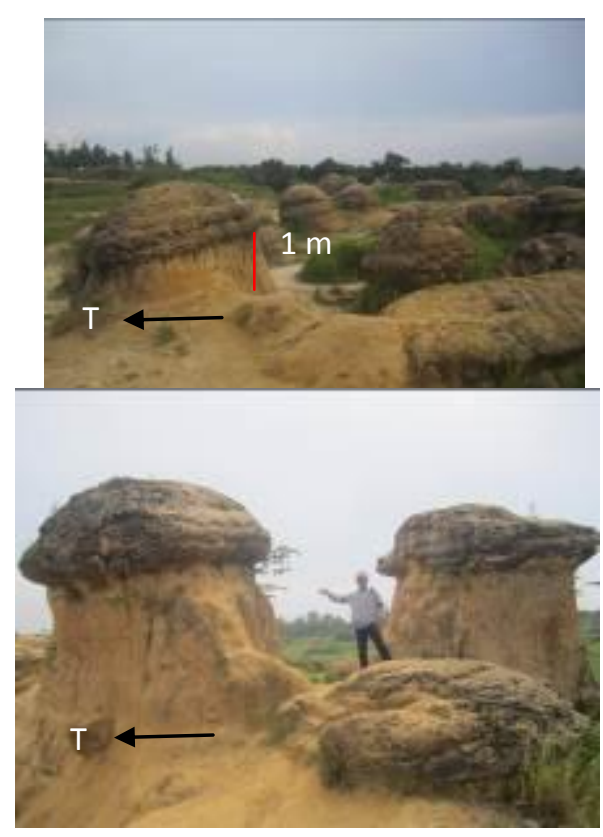

Gambar 7. Kenampakan susunan bebatuan yang unik menyerupai jamur menjadikan lokasi ini kini dijadikan sebagai obyek wisata yang cukup ramai dikunjungi oleh masyarakat namun belum dikembangkan secara optimal.

Dinding batuan disebelah timur lokasi Bukit Jamur menunjukkan kondisi awal sebelum kawasan Bukit Jamur tersebut ditambang.

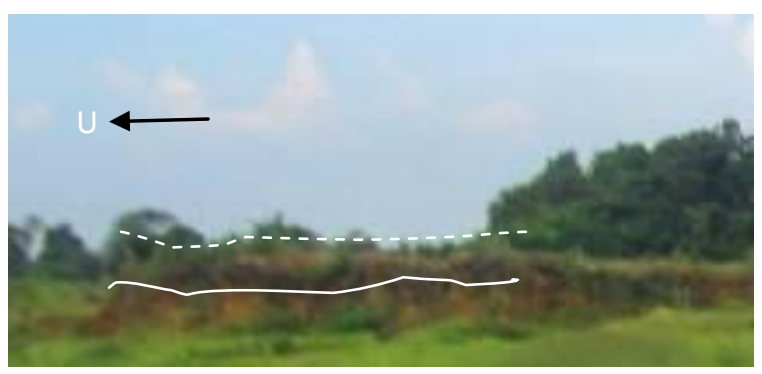

Gambar 8. Kenampakan susunan batuan penyusun Bukit Jamur sebelum dilakukan penambangan. Bagian atas dari garis putus-putus berwarna putih merupakan batu gamping terumbu yang pejal sedangkan dibagian bawahnya merupakan batu pasir karbonatan.

Meskipun bentuk jamur dari Bukit Jamur tidak terbentuk secara alami, namun secara geologi, lokasi ini tetap merupakan suatu lokasi kajian yang menarik terutama dalam bidang struktur geologi, stratigrafi, petrologi karbonat, dan mix-silisiklastik.

Lokasi ini dapat dijadikan sebagai laboratorium alam dan media pembelajaran kuliah lapangan terutama bagi mahasiswa geosains selain fungsinya sebagai objek geowisata. 


\section{Stratigrafi Daerah Penelitian}

Stratigrafi wilayah Bukit Jamur tersusun atas batu pasir karbonatan di bagian bawah dan batu gamping terumbu (bafflestone) di bagian atas.

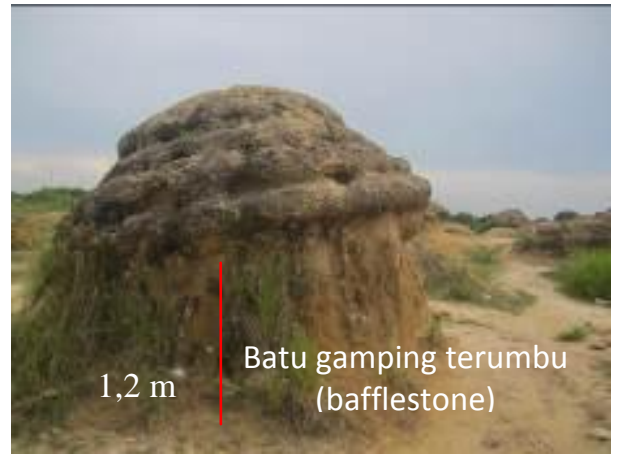

Gambar 9. Singkapan batu pasir karbonatan dan batu gamping terumbu (bafflestone), Walker(1984) di lokasi Bukit Jamur

- Batu pasir karbonatan

Batu pasir karbonatan berwarna kuning kecokelatan, tersusun atas material berukuran pasir halus, sortasi baik, kemas tertutup, struktur masif, dan bersifat karbonatan.

- Batu gamping terumbu (bafflestone)

Batu gamping terumbu (bafflestone) memiliki stuktur masif tersusun atas fosil organisme pembentuk terumbu yang didominasi oleh bryozoa $(5-18 \mathrm{~cm})$, bercabang (branching), dan branching coral $(6-12 \mathrm{~cm})$.

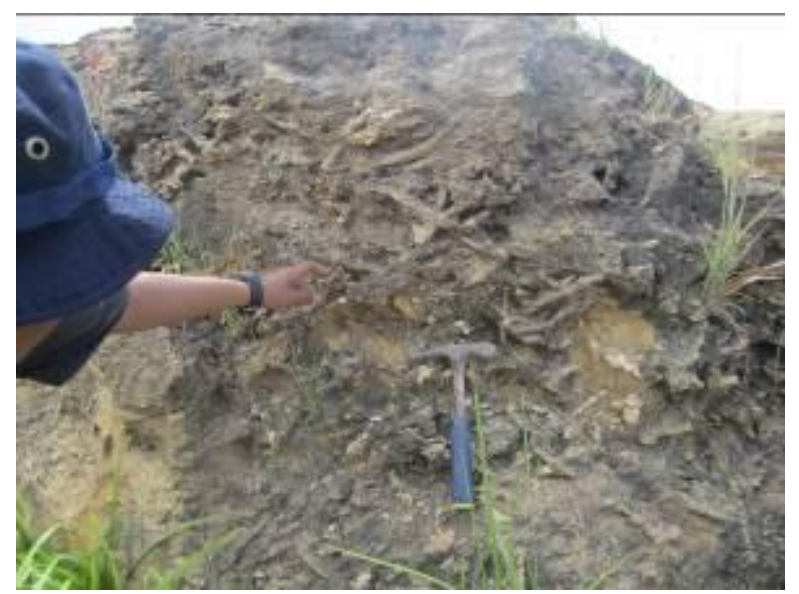

Gambar 10. Singkapan bafflestone yang lebih didominasi oleh bryozoan dan coral yang memiliki bentuk bercabang (branching).

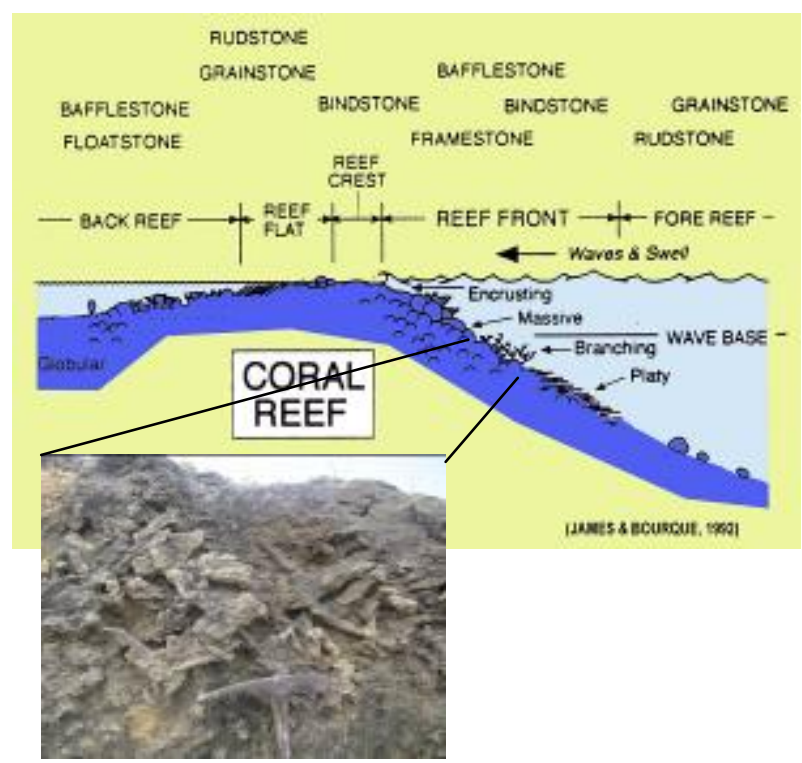

Gambar 11. Morfologi dari reef builder yang didominasi oleh bentuk branching menandakan bahwa lingkungan pembentukannya terbentuk pada energi gelombang yang tinggi (Flugel, 1982). Sedangkan sedimentasinya sangat rendah. (Miall,1984). Berdasarkan pertimbangan tersebut maka bafflestone di lokasi Bukit Jamur pada saat miosen awal-tengah terbentuk di lingkungan reef front. (James \& Borque,1992),( Reading,1996)

\section{AUTOSTRATIGRAPHY- ECOLOGICAL SUCCESSION}

\begin{tabular}{|c|c|c|c|c|}
\hline STRUCTURE & STAGE & LIMESTONE & DNERSTY & SHAPE \\
\hline t & Domnation & $\begin{array}{l}\text { Bindstone } \\
\text { Framestons }\end{array}$ & Low & $\begin{array}{l}\text { Laminate } \\
\text { Encrusting }\end{array}$ \\
\hline AEEF & Oimax & $\begin{array}{l}\text { Framestone } \\
\text { Bindstone }\end{array}$ & Hgh & $\begin{array}{l}\text { Dorral } \\
\text { Masshe } \\
\text { Lamelist } \\
\text { Branching } \\
\text { Encrusing }\end{array}$ \\
\hline \multirow{2}{*}{ MOUND } & \multirow{2}{*}{ Proneer } & $\begin{array}{l}\text { Baffestone } \\
\text { Floatstone }\end{array}$ & Lew & $\begin{array}{l}\text { Brancting } \\
\text { Lametar }\end{array}$ \\
\hline & & $\begin{array}{l}\text { Iransione } \\
\text { Audstone }\end{array}$ & Low & $\begin{array}{l}\text { Skeletal } \\
\text { Debris }\end{array}$ \\
\hline
\end{tabular}

Gambar 12. Ditinjau dari tahapan perkembangan terumbu (stage of reef growth). Reef pada kawasan Bukit Jamur memasuki fase kolonisasi dimana diversitas organisme nya rendah dan didominasi oleh bentuk bercabang (branching) dan lamellar.

(James \& Borque,1992). 


\section{PENUTUP}

\section{Kesimpulan}

1. Bukit Jamur di Kecamatan Bungah, Kabupaten Gresik memiliki keunikan dan nilai estetika sehingga layak untuk dijadikan sebagai suatu kawasan wisata.

2. Bukit Jamur dapat dikatakan menarik dari sudut pandang geologi, karena merupakan bagian dari puncak Antiklin Bungah, tersusun atas batu pasir karbonatan dan batu gamping terumbu (bafflestone) sehingga dapat dijadikan sebagai laboratorium alam untuk kuliah lapangan mahasiswa geosains sekaligus sebagai objek geowisata.

3. Bafflestone di Bukit Jamur didominasi oleh bryozoan dan branching coral. Lingkungan pembentukannya adalah reef front dan tahapan perkembangan terumbunya memasuki fase kolonisasi.

\section{DAFTAR PUSTAKA}

Boggs,S.Jr., 2006. Principle of Sedimentology and Stratigraphy. Merrill Publishing, Company, Ohio

Flügel, E, 1982. Microfacies Analysis of Limestone. Springer-Verlag, Germany.

James, N.P., Bourque, P-A., 1992. Reefs and mounds. In: Walker,R.G., James, N.P. (Eds.), Facies Models, Response to Sea Level Change. Geol. Assoc. Can., Geotext, 1, hh. 323-347

Miall, 1984. Principles of Sedimentary Basin Analysis. Springer-Verlag Inc., New York.

Reading,H.G., 1996. Sedimentary Environment, Process, Facies, and Stratigraphy. Blackwell science, London.

Supandjono, B.,J.,Hasan,K.,Satria,D., Sukardi, 1992. Peta Geologi Lembar Surabaya \& Sapulu, Jaw. Pusat Penelitian dan Pengembangan Geologi.

Walker, R.G., Editor, 1984. Facies Models. 2nd Ed., The Geological Association of Canada, Ontario. 